\title{
LIVRINHOS QUE ERAM VERDADEIROS TESOUROS: LEITURAS PARA CRIANÇAS NO BRASIL IMPERIAL
}

\author{
Carlos Antônio Pereira Gonçalves Filho ${ }^{1}$ \\ Universidade Federal de Pernambuco (UFPE) \\ carlos.historia7@hotmail.com
}

RESUMO:

Este artigo apresenta uma breve análise de duas obras voltadas à educação do público infantil durante o século XIX: o Tesouro de Meninas e o seu congênere, o Tesouro de Meninos. Publicados originalmente na Europa, estes livros ajudaram a difundir modelos de comportamento para os/as filhos/as das camadas médias e altas da sociedade brasileira do Império. O conteúdo dessas obras mesclava lições de história, geografia e ciências naturais com lições de ordem moral constituindo um compêndio de conhecimentos gerais para uso nas escolas e na educação doméstica. Os textos destes livros foram compostos no formato de diálogos em que um personagem adulto ensina às crianças as regras do bem viver dentro e fora de casa. Como recursos didáticos, estes livros se valiam de contos, fábulas e biografias de celebridades históricas, de modo a introjetarem nos/as pequenos/as leitores/as os exemplos de conduta que deveriam seguir. Através de suas páginas, meninos e meninas deveriam aprender, assim, a representar os papéis sociais almejados por seus progenitores numa sociedade organicamente constituída.

Palavras-chave: Educação, Obras Educativas, Gênero, Infância.

\section{BOOKLETS THAT WERE TRUE TREASURES: READINGS FOR CHILDREN IN IMPERIAL BRAZIL}

\begin{abstract}
:
This article presents a brief analysis of two projects aimed at educating the child audience during the nineteenth century: the Treasury for Girls and its counterpart, Treasury for Boys. Originally published in Europe, these books helped disseminate models of behavior for the middle and upper classes children of the Brazilian society during the Empire. The content of these works blended lessons of history, geography and natural sciences with moral lessons, comprising a compendium of general knowledge for use in schools and home education. The texts of these books were composed in the form of dialogues in which an adult character teaches children the rules of the good life inside and outside the home. As educational resources, these books were full of stories, fables and biographies of historical celebrities in order to introject in the little readers the examples of conduct that should follow. Through its pages, boys and girls should learn to represent social roles pursued by their parents in a society organically formed.
\end{abstract}

Keywords: Education, Educative Works, Gender, Childhood. 


\section{Sobre a categoria "gênero": ligeira introdução.}

Do ponto de vista gramatical, o gênero tem como função identificar substantivos masculinos e femininos. Mas o seu uso atual vai muito além da colocação de um "o" ou um "a" em uma palavra ou oração. A partir da segunda metade do século passado, o gênero incorporou um novo significado transformando-se em um instrumento para se compreender as relações sociais. Seu emprego dentro de uma nova significação se deu, pela primeira vez, em 1955, mas foi com o psicanalista Robert Jesse Stoller, em 1968, que foi posta de maneira mais contundente a sua nova função. $O$ gênero, então, passou a ser utilizado também para "clarificar a distinção entre o biológico e o cultural, no que se refere às diferenças e às desigualdades entre os homens e as mulheres, mostrando que diferenças biológicas se haviam convertido em desigualdades sociais". A palavra "gênero" foi sendo cada vez mais incorporada ao vocabulário não só de antropólogos, sociólogos e psicólogos, mas também ao de feministas que passaram a utilizá-la em substituição a termos como "sexo" ou "diferença sexual"3.

Em 1986, com a publicação de seu artigo Gênero: uma categoria útil para a análise histórica, a pesquisadora norte-americana, Joan Wallach Scott, problematizou o significado e o uso da categoria gênero aludindo às possibilidades de seu emprego por parte dos (as) historiadores (as). Scott definiu o gênero como "um elemento constitutivo de relações sociais baseado nas diferenças percebidas entre os sexos", e, também, como "uma forma primeira de significar as relações de poder". (SCOTT, 1996, p. 14).

O gênero, na perspectiva de Scott, é um, dentre outros fatores, que constituem as relações sociais; é, por assim dizer, um elemento pelo qual as pessoas significam a si próprias e ao mundo. Esta significação, por sua vez, não se baseia em nenhum aspecto econômico, étnico ou religioso (o que não quer dizer que estes fatores não interfiram de algum modo), mas sim nas diferenças que são percebidas entre os sexos. Esta percepção gera um saber sobre o sexo, um saber-poder que

não se refere apenas a ideias, mas a instituições e estruturas, práticas cotidianas e rituais específicos, já que todos constituem relações sociais. O saber é um modo de ordenar o mundo e, como tal, não antecede a organização social, mas é inseparável dela. (SCOTT, 1994, p. 12-13).

Este saber, segundo Scott, estabelece significados para as diferenças sexuais que "variam de acordo com as culturas, os grupos sociais e no tempo, já que nada no corpo, incluídos aí os órgãos reprodutivos femininos, determina univocamente como a divisão social será definida". (SCOTT, 1994, p. 13). Diante disso, para os (as) historiadores (as) a questão que se coloca é precisamente esta: quais são e em que contextos são formulados os significados de um "verdadeiro homem" e de uma "verdadeira mulher" em uma dada sociedade e em um dado momento? Em outras palavras, podemos dizer que a pesquisa histórica do gênero busca entender os modos e os motivos que engendraram uma determinada concepção de ser-homem ou mulher; uma concepção que não se restringe à identidade deste ou daquele gênero, mas que também serve de parâmetro para as relações internas entre as mulheres ou entre os próprios homens.

Entretanto, Scott não foi a única a teorizar sobre o assunto. Outros pesquisadores como Thomas Laqueur e Judith Butler também exploraram a categoria, porém, sobre outro ponto de vista. Para Laqueur, o gênero não pode ser apartado do sexo, ainda mais seguindo uma ordem que coloca este último precedendo o primeiro. A rigor, não haveria o sexo em si, mas o próprio gênero. Este último seria, por assim dizer, o elemento primário, "real", 
enquanto o sexo seria seu epifenômeno. Laqueur, neste sentido, inverte a "ordem das coisas" colocando o "sexo" como uma "invenção de gênero". Para provar sua tese, ele demonstra que foi somente a partir do século XVIII que os médicos e os anatomistas passaram a pensar e a perceberem o corpo humano em termos de sexo masculino e feminino. Antes disso, o que se tinha era o modelo de sexo único, masculino, tomado também como parâmetro para o corpo feminino. Desta forma, as diferenças sexuais só passaram a existir quando instituídas pelo gênero, ou seja

quase tudo que se queira dizer sobre sexo - de qualquer forma que o sexo seja compreendido - já contém em si uma reivindicação sobre o gênero. O sexo, tanto no mundo de sexo único como no de dois sexos, é situacional; é explicável apenas dentro do contexto da luta sobre gênero e poder. (LAQUEUR, 2001, p. 23).

A referência ao caráter situacional do sexo também é compartilhada por Judith Butler. Para ela,

se o caráter imutável do sexo é contestável, talvez o próprio construto chamado "sexo" seja tão culturalmente construído quanto o gênero; a rigor, talvez o sexo sempre tenha sido o gênero, de tal forma que a distinção entre sexo e gênero revela-se absolutamente nenhuma. (BUTLER, 2003, p. 25).

A perspectiva de Butler ainda é mais problemática que a de Laqueur, na medida em que ela considera o sexo, ou melhor, o "corpo-gênero" como performático, em suma, puramente discursivo quebrando com qualquer aspecto naturalizante que se pretenda para tal (BUTLER, 2003, p. 194). Segundo Pedro (2005, p. 92), as ideias de Laqueur e Butler a respeito do gênero buscam questionar o sexo enquanto um significante sobre o qual se constrói o significado; o sexo, neste sentido, passa a ser questionado na sua suposta materialidade neutra colocando-o, desta forma, como um discurso.

Não devemos crer que estas posições representem um modelo definitivo, como se os estudos de gênero seguissem uma escala evolutiva numa linha ascendente e sempre reta. O debate está aberto e sugere que esta categoria ainda terá muitas leituras por meio de caminhos tortuosos ou imprevisíveis. Aqui não pretendemos altercar com nenhuma destas posturas. Nossa intenção é a de procurar entender como determinados recursos pedagógicos eram utilizados no intuito de conformar uma ideia de homem e de mulher no século XIX. A escolha de uma ou outra linha teórica não exclui um denominador comum: ser mulher ou ser homem pressupõe algo que extrapola a simples constatação anatômica dos corpos; algo que diz respeito a atitudes, modos, expressões e linguagens que caracterizam os sujeitos imprimindo-os uma identidade de gênero. Segue-se daí que o nosso olhar deve estar voltado para o modo como meninos e meninas aprendiam a ser homens e mulheres, de fato. Em outras palavras, devemos nos voltar para a educação...

\section{O ensino dos saberes e o saber ser}

Segundo um dicionário da língua portuguesa muito usado no oitocentos, a educação era definida como a "criação que se faz em alguém ou se lhe dá; ensino das coisas que aperfeiçoam o entendimento ou servem de dirigir a vontade e, também do que 
respeita ao decoro". (SILVA, t. I, 1922) ${ }^{4}$. Dois termos se destacam nesta definição: criação e ensino. No que tange ao primeiro, há um componente material e imaterial presente na noção de criar: a criança é amparada nas suas necessidades físicas e psicológicas. A criação abarca tanto o "sustento" quanto o desenvolvimento social do individuo. Já o termo ensino aparece como se referindo a "conselho", "direções", "preceitos". Uma pessoa com "bom ensino" seria alguém que se portava com "urbanidade". Por outro lado, o "mau ensino", indicava "descortesia". Mas se o termo "ensino" estava associado ao aprendizado das boas maneiras, ele também assumia o significado de "instrução". Por "instruir", entendia-se "ensinar" a alguém uma "arte, ciência ou qualquer coisa que ele ignore". O "instrutor" é, assim, aquele que "instrui", "ensina”. Neste sentido, o "ensino das coisas que aperfeiçoam o entendimento" pode ser visto como o aprendizado dos saberes necessários à vida prática, uma cultura geral que tinha o consenso dos contemporâneos; era a instrução propriamente dita que abarcava o aprendizado dos idiomas (francês e inglês), da gramática, da matemática, das histórias (sagrada e nacional), da música (piano), das prendas domésticas (costura, bordado), dentre outros. Em contrapartida, temos o ensino das coisas que "servem de dirigir a vontade e, também do que respeita ao decoro". Esta segunda parte da definição trata do comportamento dos indivíduos, da maneira como se deviam mostrar e se relacionar, das atitudes que deveriam assumir perante a sociedade. Ao indivíduo não bastava ser instruído em alguma arte, ciência ou idioma. Tinha que saber se portar, agindo conforme os códigos sociais e padrões de moralidade da época para granjear a estima e aceitação de seus pares. Ou seja, era preciso ter em conta não só o ensino dos saberes (instrução), mas também o saber ser (comportamento).

Nas chamadas "escolas de primeiras letras", o ensino dos saberes correspondia às lições de leitura, escrita e cálculo, este último incluindo "as quatro operações de aritmética, prática de quebrados, decimais e proporções", além das "noções mais gerais de geometria prática", como consta na Lei Geral do Ensino de $1827^{5}$. Claro que, neste caso, tratava-se de um currículo destinado aos meninos. No caso das meninas, a lei excluía as "noções de geometria" e limitava a "instrução de aritmética só as suas quatro operações" com a inclusão, por outro lado, das "prendas que servem à economia doméstica" 6 . Em comum, para ambos os sexos, estariam o estudo da gramática, os princípios de moral cristã e doutrinação católica, além do texto constitucional e da História do Brasil. No que tange ao ensino do saber ser dentro do ambiente escolar, este poderia ocorrer de duas maneiras: através da leitura de textos especialmente voltados aos aspectos comportamentais e pela observação das práticas dos (as) educadores (as). Na imprensa do século XIX é comum encontrarmos anúncios de professores exaltando, além da qualidade do ensino de suas aulas, o aspecto ordeiro e moral de suas escolas ${ }^{7}$. Assim, por exemplo, os pais que confiassem seus filhos ao professor Antônio Pinto da Silva Freire poderiam estar certos de que nas suas aulas se conciliava "a urbanidade e estima com o respeito" ". A disciplina deveria ser observada com especial atenção (pelo menos em tese), porque o bom mestre tinha que mostrar aos seus alunos que "um menino atento, dócil e trabalhador é bom companheiro e será depois bom filho, bom pai e bom cidadão" ". No caso das docentes, a referência à "honestidade" e estado matrimonial são recorrentes. Ser casada dava certo respaldo moral à professora, já que sendo esta esposa, estaria, assim, conduzindo sua vida de forma reta, servindo de modelo para suas pupilas. No caso de ser separada ou viúva, a opinião pública podia contar a seu respeito. Era o "ouvir-dizer" que poderia garantir ou refutar o seu atestado moral. As informações circulavam pela cidade através das bocas as mais diversas e não seria impossível deduzir que as professoras soubessem que os pais de suas alunas procederiam a um prévio exame de suas "vidas privadas" antes de fecharem o "negócio"". 
Mas além da conduta docente, o saber ser também se aprendia pela leitura. E que leitura seria esta? Na escola que a professora Maria Lacerda Villa Secca mantinha na Rua do Imperador, no Recife, se aprendia a ler através das "cartas de sílabas" e, depois, as alunas eram apresentadas a obras como Moral em Ação e Tesouro de Meninas ${ }^{11}$. Estes títulos são encontrados com certa facilidade nos anúncios da imprensa pernambucana do oitocentos. Não só estes. Outros títulos também eram indicados aos pais e mestres, pois continham preceitos que ajudavam a "trabalhar as virtudes" nas crianças ${ }^{12}$. Uma análise destas obras destinadas à formação das gerações passadas pode nos fornecer indicativos do modo como eram selecionados e apresentados determinados saberes considerados pertinentes de serem repassados às crianças. Um texto voltado para fins didáticos será sempre portador de um discurso, de um determinado modo de ver as coisas que é referendado por uma sociedade ou parte dela. Por trás de cada "lição" lida há sempre, no jeito como é apresentado ou discutido tal assunto, uma intenção, um desejo, uma vontade de que aquele ou aquela que irá ler o texto assimile uma ideia, um comportamento, uma atitude. Desta forma, a leitura de tais livros pode ser reveladora de intenções e representações que se escondem em meio às suas histórias, figuras e páginas. Tendo este objetivo em vista, faremos uma breve leitura de dois destes livros direcionados ao público infantil no século XIX.

\section{Tesouro de Meninas}

Comecemos pelo clássico da francesa Jeanne Marie Leprince de Beaumont (17111780), o Tesouro de Meninas. A primeira edição deste livro saiu em 1758 e, em pouco tempo, alcançou um enorme sucesso editorial. Segundo Ana Maria Machado

tratava-se, originalmente, de uma coletânea em dois volumes reunindo vários números de uma revista que a escritora criara pouco antes, uma compilação literária e científica para jovens leitores. (MACHADO In: LEPRINCE DE BEAUMONT, 2008, p. 7-8).

O sucesso de público se deveu, em parte, ao fato de que se tratava de um texto deliberadamente voltado aos (às) leitores (as) iniciantes, ainda que sua linguagem esteja muito distante da que hoje em dia se vê nos livros do gênero. Apesar disto, Machado considera Leprince de Beaumont uma das precursoras deste tipo de literatura, já que o seu Tesouro de Meninas foi pensado pedagogicamente para atender às necessidades de formação das crianças. (MACHADO In: LEPRINCE DE BEAUMONT, 2008, p. 8). Em 1774 a obra foi traduzida para o português por Joaquim Inácio de Frias e sua circulação no Brasil já se fazia presente desde o final do século XVIII ${ }^{13}$. Em 1861 ela recebeu uma nova edição, desta vez publicada em Pernambuco e refundida e aumentada pelo cônego J. F dos Santos que também era professor de geografia do Seminário de Olinda.

Mas do que trata este best-seller da literatura infantil? Primeiro, atentemos para o próprio significado da palavra "tesouro" presente no título. Ela evoca, segundo Ana Maria Machado, a ideia de thesaurus, obra de referência. Ali existem conhecimentos úteis de serem apreendidos. E se é um Tesouro de Meninas, então estes são conhecimentos úteis às representantes do belo sexo. A obra é divida entre o ensino daqueles "saberes práticos para a vida", que formam uma cultura geral, e os que dizem respeito à moral. Os dois são apresentados simultaneamente no livro de Beaumont na forma de diálogos entre uma preceptora e suas discípulas. Estas são meninas abastadas que vivem em casas com muitas 
criadas e têm idades que variam dos cinco aos treze anos. Através das conversas e das histórias contadas por Bonna, a aia de uma das crianças, estas meninas aprendem importantes lições sobre ciência, história, geografia, doutrina cristã e comportamento. $\mathrm{O}$ uso que a autora faz das fábulas é constante ao longo do livro, e é a partir delas que muitas lições de ordem moral são extraídas ${ }^{14}$.

A primeira história do livro, Conto do príncipe Amado fala de um rei muito bom que um dia, na floresta, acolheu por pena, um coelho perseguido por cães ferozes. Levando o animal para o palácio admirou-se de o ver, de repente, transformado numa fada. Esta, para recompensar o rei de sua boa ação, concedeu-lhe a ventura de pedir o que quer que fosse, pois para uma fada cheia de poderes nada era impossível. O rei desejou apenas que seu filho, o príncipe Amado, fosse o melhor entre todos os príncipes, o mais virtuoso e bondoso. A fada concordou, mas advertiu ao rei que, neste caso,

é preciso que ele faça por si mesmo para o ser. O que eu posso fazer é dar-lhe bons conselhos, repreendê-lo das suas faltas e castigá-lo, se não quiser emendar-se, e castigar-se a si próprio. (LEPRINCE DE BEAUMONT, 2008, p. 47).

Transcorrido algum tempo, o rei morreu e a fada apareceu ao príncipe dizendo-lhe que pela promessa feita ao seu pai ela se tornaria sua guia dali por diante. Dizendo isso, entregou-lhe um anel mágico que tinha a função de lhe picar o dedo toda vez que Amado fizesse alguma má ação. No começo ia tudo bem e o anel não teve ensejo de lhe ferir o dedo. Com o passar do tempo, Amado foi cometendo más ações, de modo que o anel passou a incomodá-lo. Amado, porém, não se importou e arrancou fora o anel para se ver livre daquelas picadas. Assim, ele foi se tornando cada vez pior e suas atitudes desapontavam os súditos do reino. $\mathrm{O}$ ápice de sua maldade foi quando tentou casar à força com uma moça aprisionando-a no palácio. A moça fugiu, e, quando Amado preparava a sua vingança, eis que surge a fada para lhe aplicar um horrendo castigo: transforma-o num monstro. Reduzido a este estado medonho, Amado foi tratado como todas as feras: foi capturado, enjaulado, comeu sobras e serviu de espetáculo para os súditos do reino. Sua situação só começou a melhorar quando ele passou a fazer boas ações, ajudando as pessoas. Desta maneira, ele foi "evoluindo" para formas mais "nobres" como cachorro, pombo e, finalmente, homem - esta última transformação devida ao amor que a moça, que ele havia anteriormente maltratado, passou a devotá-lo. Daí em diante, Amado tornara-se um rei a tal ponto virtuoso que nunca mais o anel que ele havia recolocado no dedo lhe picou.

Ao final da história, Bonna, a preceptora, instiga suas discípulas a relatarem suas impressões e extrair-lhe as lições, como no diálogo abaixo:

\section{BONNA}

Dizei, Sensata, a estas meninas o que se deve fazer depois que se aprende ou ouve alguma história.

SENSATA

Vós me tendes dito que se devem examinar os vícios e as virtudes daqueles de quem se leem as histórias para evitarmos os mesmos erros e praticar as suas virtudes. (LEPRINCE DE BEUMONT, 2008, p. 65).

A história do príncipe Amado fala da importância de agir bem com as pessoas, de não ser egoísta, tirano, pois os que assim agem ficam com a sua alma feia, "e mais 
abominável que um monstro" - afirma Bonna. Diante disso, uma das discípulas entrega o jogo:

\section{CARLOTA}

Eu tenho bem desejo de ser boa; e se muitas vezes sou má e cometo alguma loucura é sem considerá-lo. Eu não quero que me desmintam; e quando se me nega o desejo, faço-me então má, castigo a minha criada, injurio minhas irmãs e zombo de meus pais; mas, para evitar isto, peçovos que me digais o que devo fazer. (LEPRINCE DE BEAUMONT, 2008, p. 60-61).

Os conselhos de Bonna para corrigir o mau comportamento de Carlota incluem orações, pedido de perdão à criada e às irmãs, bem como um exercício de reflexão para ser feito todas as noites: escrever as más palavras ditas durante o dia, pois assim o fazendo Carlota iria sentir vergonha de si mesma (LEPRINCE DE BEAUMONT, 2008, p. 61). É bom lembrar que este é um livro escrito na Europa e dirigido às crianças de famílias abastadas. Famílias com criadas, mas não com escravas. Em outra passagem do livro, Bonna afirma que não se deveriam tratar mal os criados, pois estes já levavam uma vida difícil, trabalhando duro para conseguir o seu sustento. Se fossem maltratados, além de ficarem mais infelizes, também não desempenhariam bem o seu serviço. "Os maus amos é que fazem os maus criados" - adverte Bonna (LEPRINCE DE BEAUMONT, 2008, p. 130). Mas e no caso das pequenas leitoras brasileiras do século XIX rodeadas de escravos (as) por todos os lados? Como seria interpretada esta passagem do perdão e do bom tratamento reservado às criadas?

As fábulas no Tesouro de Meninas são entrecortadas também com narrativas bíblicas, a exemplo do pecado original. Não se trata do texto extraído direto das Sagradas Escrituras, mas de uma adaptação que apresenta uma linguagem mais acessível às leitoras. O destaque da desobediência de Eva no episódio do fruto proibido é ressaltado, assim como a postura dos irmãos Caim e Abel que são tomados como exemplos de comportamentos distintos e necessários de serem observados pelas meninas, como transparece neste diálogo:

\section{CARLOTA}

Pois então eu a digo: Olhai, eu sou invejosa como Caim a respeito de minha irmã mais velha: meus pais a amam mais do que a mim, e isto me faz desesperar, e certamente eu a mataria, se pudesse.

\section{BONNA}

E não é por vossa culpa que vossos pais amam vossa irmã mais do que vós? Diz-me: se fôsseis casada e tivésseis duas filhas, das quais uma fosse agradável, honesta, obediente e dócil a seus mestres, e a outra teimosa, maligna, descortês para todos e desobediente aos mestres, qual amaríeis vós mais?

\section{CARLOTA}

A primeira.

\section{BONNA}

Logo não deveis ofender-vos de vossos pais quererem mais a vossa irmã do que a vós: fazei-vos vós tão boa como ela, e então, vereis como eles vos estimam preciosamente. (LEPRINCE DE BEAUMONT, 2008, p. 70). 
Doçura, obediência e honestidade são as qualidades que fariam Carlota ser aceita por seus pais. Qualidades esperadas numa moça que também incluíam outros atributos, tais como os que aparecem no conto A Bela e a Fera, incluído no Tesouro de Meninas por Leprince de Beaumont. Segundo Ana Maria Machado, este conto fora abreviado em sua extensão da obra originalmente escrita por Gabrielle Suzanne de Villeneuve (MACHADO In: LEPRINCE DE BEAUMONT, 2008, p. 14). A versão do Tesouro conta a história de um mercador rico que perde toda a fortuna e se vê obrigado a deixar a cidade para ir trabalhar no campo com seus filhos: três homens e três mulheres. Como não havia mais luxo, todos tinham que trabalhar na fazenda como verdadeiros camponeses. De todos, a mais dedicada era Bela, a caçula, que se levantava ainda de madrugada e dedicava o seu tempo a arrumar a casa, cozinhar e fazer todo o serviço necessário ao arranjo da família. Um dia, o pai recebe a notícia que um de seus navios, que julgara perdido, havia chegado com várias mercadorias. De pronto, decide ir ao porto na esperança de melhorar sua situação financeira. Na saída, as irmãs de Bela pediram ao pai que trouxesse "vestidos, palatinas, toucados e toda a sorte de enfeites". Elas nunca haviam se conformado com aquela vida de privações, e sonhavam em voltar ao fausto da cidade. Bela, ao contrário, não pedia nada e, como seu pai insistisse muito, ela lhe pediu apenas uma singela rosa. Indo o pai ao porto, teve a decepção de ter sua carga roubada. Voltou para casa do mesmo jeito que partira, mas antes de chegar, perdeu-se numa floresta e ficou vagando a esmo por horas até que vislumbrou um palácio todo iluminado. Aparentemente desabitado, o lugar estava, no entanto, preparado para receber um hóspede: havia uma mesa posta, feno para o cavalo, e uma confortável cama para dormir. Ao acordar, pela manhã, tudo era só felicidade: no lugar de sua roupa velha, havia uma nova e a mesa estava cheia de iguarias de chocolate. Antes de montar em seu cavalo para seguir viagem, o ex-mercador apanhou um ramo de rosas para levar de presente à Bela. Neste mesmo instante aparece uma criatura medonha, a Fera. Ela faz saber que naquele palácio tudo podia ser desfrutado, mas nada levado e, como o desafortunado viajante arrancasse as rosas do jardim, ele haveria de pagar o delito com a sua própria vida. Depois de muito implorar, recebe da Fera o consentimento para retornar à sua casa e a garantia do perdão, caso uma de suas filhas morresse em seu lugar. Chegando ao lar, conta o que se passara e Bela se oferece para o sacrifício. Para encurtar a história: Bela realmente foi para o Palácio, mas em vez de ser devorada pela Fera acabou conquistando-lhe o coração pelas suas atitudes de abnegação e dedicação à sua família. Sim, a Fera também tinha um coração, e Bela soube cativá-lo por detrás daquela horrível aparência. Na verdade, Bela ficou nutrindo um amor pela Fera e esta passou a tratá-la com um carinho todo especial. Apesar disso, Bela não podia esquecer o seu pai. Seu coração estava dividido. Esta situação, que a fazia sofrer muito, encontrou o seu desfecho quando a Fera se revelou um lindo príncipe que desposou Bela e foram, ambos, felizes para sempre.

O desapego de si e a dedicação aos seus marca a personalidade de Bela. Sua maior riqueza era sua virtude. Bela não valorizava as aparências como suas irmãs, não se importava com vestidos caros e ornamentos, mas sim com o trabalho, com o desempenho de suas tarefas domésticas expressando grande amor filial. Esta personalidade facilitou o seu convívio com a Fera. Ela não se fiou pelo exterior da criatura, mas procurou valorizar o que ela tinha de melhor através de suas ações. E como fez o que era certo não se importando com os perigos, foi recompensada casando-se com um "príncipe encantado" (nessas histórias é comum figuras monstruosas se transformarem em príncipes quando o "encanto" ou "feitiço" é quebrado, geralmente por um gesto ou uma atitude benigna carregada de virtuosidade que redime o enfeitiçado). 
Ao longo do Tesouro de Meninas outras histórias vão sendo narradas; histórias que abordam exemplos de comportamentos que deveriam ser seguidos ou evitados por aquelas candidatas a futuras mães e esposas. Um dos vícios combatidos nessas narrativas era o da "mulher mexeriqueira". Ela aparece na história de uma menina que tinha a funesta mania de sempre inventar coisas dos outros. De tanto contar mentiras, a menina acabava provocando mal entendidos e prejudicando as relações comerciais, os casamentos e as amizades de toda uma cidade. Ela sempre jurava aos seus pais que nunca mais iria fofocar, mas o vício permaneceu e acompanhou-a na idade adulta. Casou, e nem assim deixou ela de fazer os seus "mexericos" até que um dia, envolvendo o nome do seu próprio marido em suas fofocas, levou-o a um duelo onde acabou perdendo a vida (LEPRINCE DE BEAUMONT, 2008, p. 155-163).

Em outra história, o tema é o da mulher de "mau gênio", uma mulher áspera que gostava de castigar os criados e os filhos, a tal ponto que estes últimos e o seu marido morreram. Sendo jovem, bela e rica era natural que alguém se interessasse em desposá-la, mas ninguém queria uma mulher furiosa como aquela. Somente um cavalheiro, seu vizinho, teve o ímpeto para tal. Advertido por um amigo do perigo que correria ao se unir àquela mulher, o cavalheiro obtemperou: "antes que passe um mês, hei de tornar esta mulher tão branda como um cordeiro”. Foi o que fez. Através de várias ações que incluíam ameaças e atos de violência ele conseguiu modificar as atitudes da mulher. A transformação foi tão grande que causou admiração a todos. Em uma das passagens da narrativa, por exemplo, o cavalheiro obriga a sua nova esposa a levar uma sela de montaria nas costas até a casa dos nubentes. Intimidada ante o tom imperial e ameaçador daquele homem que não titubeava em fazer uso da pistola, ela obedeceu "sem se atrever a proferir a palavra". Ao final da história, o marido alegava seu comportamento da seguinte forma:

Eu trato as pessoas como elas me tratam; [...] o vosso procedimento regulará o meu, e só de vós dependerás o serdes comigo a mais feliz de todas as mulheres, porém, lembrai-vos que se quiserdes zombar comigo, como o fizestes com vosso defunto marido, achareis em mim um gênio cem vezes pior do que o vosso. (LEPRINCE DE BEAUMONT, 2008, p. 195).

Em seu conjunto, as histórias narradas no Tesouro de Meninas contribuem para conformar uma ideia do ser-mulher. Comportamentos, valores e princípios são arrolados no texto de maneira a caracterizar um modo de vida próprio para o sexo feminino. Também é apontado o que deveria ser evitado, o que era considerado um vício, um mau hábito. Nas histórias, todos os atos geram uma consequiência para si e para os outros, seja esta boa ou má. Tudo iria depender das escolhas a fazer: Bela escolheu cumprir seus deveres de filha, agüentando calada todas as vicissitudes da vida e terminou se casando com um príncipe; a mulher que só queria fofocar acabou perdendo o marido num duelo; a outra, insubmissa e furiosa, acabou subjugada por um homem mais "teimoso" do que ela; Carlota, por seu comportamento desobediente, era preterida pela irmã mais velha; por tratar mal a todos, Amado foi transformado em um monstro tendo, seu exemplo, servido para levantar o debate acerca das relações domésticas entre as meninas, as criadas e a família como um todo. Nas páginas do Tesouro de Meninas, as atitudes valem mais do que as aparências. É por isto que são criticadas as vaidades, os excessos de enfeites, o luxo. A mulher vale mais pelo que é do que pelos atributos externos. Por isso, Bonna enfatiza a importância de sua formação desde a infância: 
Babiolla está acostumada a brincar todo o dia, e por isso lhe desagrada tudo que não é brinco: há de ser uma ignorante e néscia toda a sua vida, e ainda que tenha boas disposições, parecerá nos ajuntamentos uma tonta. (LEPRINCE DE BEAUMONT, 2008, p. 62).

\section{Tesouro de Meninos}

O sucesso alcançado com o Tesouro de Meninas teria motivado sua autora, segundo Ana Maria Machado, a escrever outra versão, desta vez destinada ao público masculino e que teria sido editada em português em 1813 (MACHADO In: LEPRINCE DE BEAUMONT, 2008, p. 10). Desta obra não tivemos acesso, mas sim ao livro de Pedro Blanchard. Apesar de ostentar o título de Tesouro de Meninos, ela não era inteiramente voltada ao chamado sexo forte. Também aqui encontramos os diálogos, mas com uma diferença: não é uma aia ou outra mulher que ensina, mas um "Pai de Famílias". As crianças são apenas duas, um casal, filhos do mesmo pai e educador. Seus nomes são Paulino e Felícia. O Tesouro de Meninos trata dos preceitos relacionados com a moral, a virtude e a civilidade. Na versão em português, impressa em Lisboa e dedicada à "mocidade portuguesa e brasileira", foram acrescidas lições de aritmética, história sagrada e geografia, além de alguns poemas ${ }^{15}$.

O diálogo principia por uma pergunta de Felícia a respeito do conceito de sociedade. Esta é definida pelo "Pai de Famílias" como sendo "a reunião de homens que vivem entre si debaixo das mesmas leis". (BLANCHARD, 1851, p. 14). A sociedade é apresentada como sendo uma característica da civilização, pois distancia os homens do estado da animalidade, contrapondo-os à barbárie e à selvageria. Manter os laços sociais é garantir a ordem e o império da lei; seu contrário, mergulha o homem no estado de um bruto brigando e matando indiscriminadamente a partir da "lei do mais forte". Ocorre que a manutenção do edifício social depende da observância destes três princípios: a moral, a virtude e a civilidade. A moral consiste em "não fazer o mal e retribuir o bem que nos é feito"; a virtude, em "ser útil aos semelhantes", "fazer sacrifícios sem a esperança de ser recompensado", ou seja, agir desinteressadamente em favor de outrem; por fim, a civilidade diz respeito às "formas exteriores do homem na sociedade". Todo o restante do livro será destinado ao desenvolvimento destes três conceitos. Vejamos os seus principais aspectos.

\section{a) Moral}

Diz o "Pai de Famílias" que a moral é "a base de quanto bem se faz no mundo". Ele aprendera este princípio de seus pais e agora transmitia aos seus filhos compondo uma herança que estes, futuramente, iriam também transmiti-la aos seus descendentes (BLANCHARD, 1851, p. 125). O primeiro bem deste patrimônio imaterial era o amor a Deus, seguido do amor aos seus progenitores. Amar a estes implicava também em obedecer-lhes sempre. Obediência tanto no cumprimento de suas ordens, quanto nos castigos recebidos. O castigo - ensina o "Pai de Famílias" - corrige os vícios nascentes evitando que os meninos malcriados, coléricos, desleixados e preguiçosos se tornem assassinos, bêbados, vadios, ladrões e toda a sorte de indivíduos em nada benéficos para a sociedade como um todo (BLANCHARD, 1851, p. 33). As crianças também tinham que pautar sua conduta pelo respeito aos mais velhos, aos irmãos e aos adultos. Entre os deveres morais que lhes cabiam saber estava o amor à pátria, entendida como "todo o país que se governa pelas mesmas leis". A justificativa estava calcada na ideia de que 
todos os homens de uma mesma pátria são como filhos de uma mãe comum; em certo sentido, eles estão ligados por deveres recíprocos, como os irmãos estão entre si. (BLANCHARD, 1851, p. 57).

b) Virtude

Mas de que adiantaria tanto amor e tanto desvelo sem ser virtuoso? O homem assim seria incompleto, ainda não totalmente integrado à vida em sociedade. A palavra virtude, explica o "Pai de Famílias", significa "força", "valor", ou seja, ela requer "ânimo" para fazermos o bem, mesmo contra o nosso interesse. O homem virtuoso se sacrifica por sua família, pela Pátria e pelo mundo; retribui o mal com o bem e sabe reprimir seus desejos, seus vícios e suas paixões, porque estes não prejudicam apenas a ele próprio, mas também aos que o cercam. Para ilustrar a lição, o "Pai de Famílias" recorre ao exemplo de Alexandre, o Grande, que por beber tanto vinho num banquete ficou fora de si a ponto de matar um de seus amigos por uma contrariedade boba (BLANCHARD, 1851, p. 137).

\section{c) Civilidade}

Por último, temos a civilidade, as "formas exteriores do homem na sociedade". Mas, como assim, exteriores? Novamente é o "Pai de Famílias" quem nos esclarece a questão. Ele começa dizendo que a civilidade compreende "todas as regras, segundo as quais nos devemos conduzir na sociedade". A civilidade - continua ele - "não é uma etiqueta inútil, mas torna a convivência entre os homens mais agradável" porque esconde as imperfeições morais tanto de nossa parte quanto dos outros (BLANCHARD, 1851, p. 160). A civilidade, portanto, tem uma função social bem definida: ela obriga-nos a absternos de tudo o que ofenderia aos outros e também a nós. Por outro lado, civilidade não se confunde com polidez. Esta, segundo o "Pai de Famílias", compõe-se de simples atenções que vêm do costume como dar um braço a uma pessoa que não precisa, por exemplo. Civilidade não; ela se exprime por um conjunto de regras convencionadas e necessárias de serem aprendidas o mais cedo possível. Assim sendo, o "Pai de Famílias" procede a um arrolamento dos gestos que tornavam a "convivência entre os homens agradável". Como são muitos, não vamos aqui nos deter no exame detalhado de cada um deles como é feito no livro. Apenas listamos alguns para fazer algumas considerações posteriores do conjunto. Vejamo-los.

I. Sempre digas "saúde" ao beber.

II. Inclines a cabeça à pessoa que espirra.

III. Não entres numa casa sem cerimônia.

IV. Não sentes de imediato numa cadeira demonstrando cansaço.

V. Não ponhas o chapéu à vista de todos.

VI. Não roas as unhas.

VII. Não metas as mãos nos cabelos.

VIII. Não metas o dedo no nariz.

\section{Comportamentos à mesa:}

IX. Se precisares escarrar, vires o rosto para o lado para não incomodar ninguém pondo o pé sobre a saliva. 
X. Assoe com moderação o nariz sem fazer um estrondo semelhante a uma trombeta.

XI. Ao espirrar, vires o rosto e cubra-o com um lenço.

XII. Não ponhas os cotovelos sobre a mesa, mas descanse os pulsos na borda da mesma.

XIII. Não fales de boca cheia.

XIV. Não fiques olhando para o prato do vizinho.

Diante dessa lista é quase impossível não fazer uma referência ao trabalho de Norbert Elias. Para este eminente sociólogo alemão, o conceito de civilidade tal como foi apresentado por Blanchard no seu Tesouro de Meninos começou a se delinear no século XVI. Ele principiou nas camadas aristocráticas europeias e um de seus ícones foi uma obra de Erasmo de Rotterdam intitulada De civilitate morum puerilium [Da civilidade em crianças] (ELIAS, 1994, p. 68). Esta obra influenciou um grupo inteiro de livros que ostentavam o título de Civilité ou Civilité puérile impressos até o final do século XVIII. E é justamente neste aspecto que o Tesouro de Meninos mais nos chama a atenção: para compor a terceira parte do seu manual (a dedicada ao tema da civilidade), Blanchard afirma que se valera de "um pequeno livro intitulado Civilidade pueril" dele tirando "o quanto me pareceu bom e conveniente aos nossos costumes atuais". (BLANCHARD, 1851, p. XI). É possível, então, que o autor tenha se utilizado de um dos títulos publicados pela influência direta da obra de Erasmo. Além disso, impressiona a sobrevivência de alguns dos gestos listados no Tesouro de Meninos no nosso tempo presente corroborando a tese de Elias de que o que consideramos ser "civilizado" é produto de um processo histórico, e não algo natural, próprio de nosso jeito de ser ${ }^{16}$.

Para ser civilizado é preciso agir como tal e isto implica um aprendizado dos modos de ser próprios do homem civilizado. Do homem e da mulher. Blanchard sabe disso e dedica várias lições a este assunto. Entre os ensinamentos ali encontrados estão os que dizem respeito às relações entre homens e mulheres. É o "Pai de Famílias" quem começa advertindo Paulino de que, em presença de mulheres, o homem deveria ser "casto" nas palavras, além de ter respeito e deferência pelo belo sexo (BLANCHARD, 1851, p. 218). Suas atitudes deveriam ser moderadas, sem excessos, pois isso poderia lhe facilitar o ingresso na casa de uma futura candidata à noiva: "sê homem honrado até mesmo nos teus divertimentos e faze com que o pai de famílias nunca tenha o menor receio de te admitir em sua casa (BLANCHARD, 1851, p. 219)". Mas se os homens tinham que ser cuidadosos nos seus atos, as mulheres ainda tinham muito mais obrigação de o sê-lo, e isto porque

a conduta de uma mulher deve ser muito mais severa que a de um homem. [...] todo mundo a julga com severidade; tem esta [a mulher] razão de mais para que nunca se esqueça de si. (BLANCHARD, 1851, p. 216).

Elas deveriam ser muito cuidadosas nos seus modos, sobretudo em se tratando da aproximação ou contato com algum rapaz. Quando saíssem à rua,

os seus olhos devem raramente andar levantados e, sobretudo, ainda menos devem, de qualquer modo, buscar as atenções dos homens; o contrário é uma indecência que anuncia alguma coisa mais que a desenvoltura. (BLANCHARD, 1851, p. 216).

Os olhos tinham algo realmente especial, porque logo adiante o "Pai de Famílias" volta a insistir no assunto: 
Os modos de olhar manifestam mui claramente quanto se passa no coração. Dá, pois, às tuas vistas, toda a expressão da modéstia e, para melhor o conseguirdes, sê modesta tu mesma: um ar desenvolto em uma mulher é coisa que repugna. Principalmente não busques a vista dos homens. Um tal hábito vem, ordinariamente, de depravação do coração e se, por acaso, uma simples inconseqüência te o faz imitar, confudir-te-ão com aquelas, cujo costume tem já alguma coisa de corrompidos. (BLANCHARD, 1851, p. 220-221).

Felícia ainda ouviu de seu pai um importante conselho sobre como se portar numa conversação. Dizia ele que em meio às pessoas, ela nunca deveria pretender brilhar em demasia, por que

há toda a satisfação em encontrar uma mulher instruída, mas quando essa pretende trazer toda a gente ao seu sentimento, ou se vangloria em fazer ostentação da sua ciência, torna-se insuportável e fica reduzida a classe das pedantes. (BLANCHARD, 1851, p. 223).

O ideal não era mostrar dotes de erudição, mas cultivar no seu interior o silêncio que era "o mais belo ornamento da mulher". (BLANCHARD, 1851, p. 223).

O Tesouro de Meninos era um manual para uso das crianças; um manual que ensinava passo a passo as regras e valores que deviam fazer parte desses futuros homens e mulheres do século XIX. Ali estão dispostas as normas que regeriam a vida pública e privada daqueles (elas) meninos e meninas expressas através de preceitos morais, virtuosos e civilizadores. Este era um livro dedicado à vida urbana, sobretudo; livro imbuído de um padrão de comportamento que no seu bojo representava o que os europeus entendiam por civilização. Na obra de Blanchard, a sociedade é compreendida como um corpo orgânico. As diferenças sucumbem à harmonia social. O império da lei e da ordem qualifica os sujeitos participantes e está na base da civilização. O contrário, ou seja, o instinto, a preponderância dos sentidos, das práticas anárquicas nos aproxima da desordem, da barbárie. Lendo o manual, meninos e meninas deveriam aprender que a razão de ser da sociedade se sustenta na moral, na virtude e na civilidade; que a moral caminha de mãos dadas com a obediência e o respeito, que a virtude é o contrário do vício e que a civilidade nos torna aptos ao convívio social, pelo menos com aqueles que compartilham dos nossos códigos de conduta. Esse conjunto de valores e regras, por outro lado, também normatizava a desigualdade entre os gêneros. Ao contrário dos homens, às mulheres não era permitida a livre expressão do pensamento, pois seria "insuportável" ver uma representante do belo sexo exibindo os "ornamentos da sua ciência". Sua instrução não poderia ser confundida com erudição. Na rua, quando adentrassem o espaço público, os olhos deveriam se conservar baixos, desviando-se dos rapazes. E, ainda que fosse inevitável o olhar ereto, este devia se conservar modesto. Um olhar poderia ter muitos significados, servir a muitos propósitos. Eles revelam "o que se passa no coração" como disse o "Pai de Famílias". Por isso, vigiá-los também significava controlar os desejos latentes, abafados, reprimidos ${ }^{17}$.

\section{Considerações finais}

Pedro Blanchard e Leprince de Beaumont tiveram seus manuais traduzidos para o português, receberam várias edições e atravessaram o Atlântico. Vieram parar nas mãos e 
nas mentes de um número incerto de crianças brasileiras. Foram escritos originalmente para meninos e meninas que desconheciam o mundo do trabalho, que viviam em casas abastadas e que deveriam ser preparados (as) para reuniões sociais, jantares e festas. Anunciados nos jornais, estes livros deviam ter alguma saída. Custavam algum dinheiro, exigiam investimento. Quem os comprou? Quem os leu? E, principalmente, como os leu? Deixo em aberto essas questões, pelo menos neste artigo. O que fica para nós destes escritos tão distantes no tempo é o contato com formas de pensamento e modos de conceber os atores sociais. Diretrizes para um ser em formação, personagem de si mesmo na tessitura de um enredo social e histórico. Aliando estes textos aos programas das escolas e à legislação da época com relação à educação, podemos agrupá-los em um único conjunto configurando aquilo que Joan Scott denominou de "conceitos normativos" da construção social dos sexos. Expressos através de doutrinas religiosas, educativas, científicas, políticas ou jurídicas, esses conceitos "tomam a forma de uma oposição binária que afirma de forma categórica e sem equívoco o sentido do masculino e do feminino". (SCOTT, 1996, p. 15). Assim, eles instituem um discurso sobre o outro firmando, deste modo, espaços, sujeitos e delimitando fronteiras do agir e do ser. Neste sentido, para que aquelas crianças advindas de famílias que se situassem em determinado patamar social viessem a se tornar reconhecidamente mulheres, mães e senhoras ou homens, pais e senhores era preciso algo mais que a simples constatação anatômica de seus corpos; era preciso que aprendessem desde cedo quais os papéis que, naturalmente, deveriam representar neste mundo. Seu aprendizado poderia ocorrer de diversas maneiras: no estudo de um currículo diferenciado, pela observação do comportamento docente, através das lições e histórias contidas nos manuais de conduta e instrução. Assim, de uma maneira ou de outra, deliberadamente ou sutilmente, cuidava-se para tornar real um modelo de adulto almejado desde o instante mesmo em que estas crianças vieram ao mundo.

\section{Referências bibliográficas}

BLANCHARD, Pedro. Tesouro de Meninos. Obra clássica divida em três partes: moral, virtude e civilidade. Vertida em português e oferecida à mocidade portuguesa e brasileira por Matheus José da Costa. Sexta edição, emendada, ornada com 16 estampas e enriquecida de extractos de poesia para facilitar a leitura dos versos, de noções preliminares de arithmetica ou as quatro operações de um compêndio de história sagrada, de breves noções de geographia, e da tabela dos reis de Portugal. Lisboa: Typographia de Antônio José da Rocha, 1851. Disponível em: $<$ http://www.caminhosdoromance.iel.unicamp.br/biblioteca/index.htm>. Acesso em: 20 ago. 2008.

BUTLER, Judith. Problemas de gênero: feminismos e subversão da identidade. Tradução de Renato Aguiar. Rio de Janeiro: Civilização Brasileira, 2003.

ELIAS, Norbert. O Processo Civilizador: uma história dos costumes. Tradução de Ruy Jungman. Rio de Janeiro: Jorge Zahar Editor, 1994.

GUIMARÃES, Maria de Fátima. Percurso no pensamento e na prática dos feminismos. Introdução à abordagem de gênero. Gênero \& História: Caderno de História do Departamento de História da UFPE. Recife, ano 1, n. 1, p.7-22, setembro de 2002. 
GOMÁRIZ, Enrique. Los estudios de género y sus fuentes epistemologicas: periodización y perspectivas. In: RODRÍGUES, Regina (Ed). Fin de siglo: género y cambio civilizatório. Santiago: Isis Internacional, 1992. p. 83-110. (Ediciones de las Mujeres, n. 17).

GONDRA, José Gonçalves; SCHUELER, Alessandra. Educação, poder e sociedade no império brasileiro. São Paulo: Cortez, 2008.

GONÇALVES, Andrea Lisly. História e Gênero. Belo Horizonte: Autêntica, 2006.

GONÇALVES FILHO, Carlos Antônio Pereira. Honradas Senhoras \& Bons Cidadãos: gênero, imprensa e sociabilidades no Recife oitocentista. Recife: Ed. Universitária da UFPE, 2010.

LAQUEUR, Thomas. Inventando o sexo: corpo e gênero dos gregos a Freud. Tradução de Vera Whately. Rio de Janeiro: Relume Dumará, 2001.

LEPRINCE DE BEAUMONT, Jeanne Marie (madame). Tesouro de Meninas ou Diálogos entre uma sábia aia e suas discípulas. Tradução de Joaquim Ignácio de Frias e refundido, corrigido e aumentado na segunda edição de 1861 por J. F dos Santos. Seleção e prefácio de Ana Maria Machado. Rio de Janeiro: Lexicon, 2008.

LUNA, Lola González. Apuntes sobre el discurso feminista en America Latina. Historia, Antropologia y Fuentes Orales. Barcelona, v. 2, n. 38, p. 145-162, 2007.

MACHADO, Ana Maria. Diálogos duradouros. In: LEPRINCE DE BEAUMONT, Jeanne Marie (madame). Tesouro de Meninas ou Diálogos entre uma sábia aia e suas discípulas. Tradução de Joaquim Ignácio de Frias e refundido, corrigido e aumentado na segunda edição de 1861 por J. F dos Santos. Seleção e prefácio de Ana Maria Machado. Rio de Janeiro: Lexicon, 2008. p. 7-24.

MATOS, Maria Izilda Santos de. Por uma História da mulher. Bauru, SP: EDUSC, 2000.

MATTOS, Ilmar R. O Tempo Saquarema: a formação do Estado Imperial. São Paulo: Hucitec, 2004.

PEDRO, Joana Maria. Traduzindo o debate: o uso da categoria gênero na pesquisa histórica. História, São Paulo, v. 24, n. 1, p. 77-98, 2005.

SILVA, Adriana Maria Paulo da. Processos de construção das práticas de escolarização em Pernambuco, em fins do século XVIII e primeira metade do século XIX. Recife: Ed. Universitária da UFPE, 2007.

SILVA, Antônio de Moraes. Diccionario de Língua Portuguesa. Ed. fac-sim da segunda edição de 1813. Tomo I. Rio de Janeiro: Litho-Typografia Fluminense, 1922.

SCOTT, Joan W. Gênero: uma categoria útil para a análise histórica. $3^{\mathrm{a}}$ ed. Tradução de Christine Rufino Dabat e Maria Betânia Ávila. Recife: SOS Corpo, 1996. 
SCOTT, Joan W. Prefácio a Gender and politics of history. Cadernos Pagu. São Paulo, n. 3, p. 11-27, 1994.

História das Mulheres. In: BURKE, Peter (org). A Escrita da História: novas perspectivas. Tradução de Magda Lopes. São Paulo: Unesp, 1992. p. 63-95.

SOINHET, Rachel. História das Mulheres. In: CARDOSO, Ciro Flamarion; VAINFAS, Ronaldo. Domínios da História: ensaios de teoria e metodologia. Rio de Janeiro: Campus, 1997. p. 275-296.

VERRI, Gilda Whitaker: Tinta sobre papel: livros e leituras em Pernambuco no século XVIII, 1759-1807. v. 2. Recife: Ed. Universitária da UFPE / Secretaria de Educação e Cultura, Pernambuco, 2006.

\section{Notas}

${ }^{1}$ Mestre em História pela Universidade Federal de Pernambuco. Doutorando em História pela mesma universidade.

${ }^{2}$ Significativo desse momento é o título do livro de Stoller, Sex and Gender. Cf. LUNA, 2007, p. 148.

${ }^{3}$ É bom destacar que o surgimento do gênero como categoria de análise social não está dissociado de um processo histórico mais amplo de luta pela igualdade de direitos sociais com relação a homens e mulheres, com especial destaque para a atuação dos movimentos feministas e de mulheres na Europa, EUA e no Brasil. Não é nossa intenção aqui reconstituir esta trajetória que remonta ao século XVIII. Sobre o assunto, há uma boa síntese em GOMÁRIZ In: RODRÍGUES, 1992. Na mesma linha, temos GUIMARÃES, 2002, GONÇALVES, 2006 e MATOS, 2000. Sobre a renovação da historiografia com a introdução dos estudos sobre mulheres e do gênero ver SCOTT In: BURKE, 1992. Seguindo a mesma discussão com foco nas pesquisas brasileiras temos SOINHET In: CARDOSO; VAINFAS, 1997.

${ }^{4}$ Além desta, também fizemos uso da edição de 1789 composta pelo padre Rafael Bluteau disponível em: <http://www.brasiliana.usp.br/bbd/handle/1918/00299210\#page/1/mode/2up〉. Acesso em: 19 jan. 2011. Neste artigo, nos atemos à primeira metade do século XIX.

5 BRASIL, Lei Geral do Ensino de 15 de outubro de 1827. Disponível em: <http://www.histedbr.fae.unicamp.br/navegando/fontes_escritas/3_Imperio/lei\%2015-101827\%20lei\%20do\%20ensino\%20de\%20primeiras\%20letras.htm>. Acesso em: 20 jul. 2007.

${ }^{6}$ Segundo Ilmar Mattos, o estudo mais aprofundado da Matemática, incluindo a Geometria e os números decimais, além das regras de porcentagem, dotava o indivíduo das condições necessárias para apreender as "estruturas lógicas elementares presentes no mundo, e que fundamentavam o primado da razão". (MATTOS, 2004, p. 276). Desta abstração, deste mergulho nas "estruturas lógicas elementares", as meninas só deveriam ter o domínio das "quatro operações" que, aliadas ao conhecimento da escrita, da gramática e das "prendas domésticas", habilitava as jovens brasileiras ao mundo da casa e tudo que se relacionasse ao seu arranjo.

${ }^{7}$ A moralidade docente incluía a sua conduta familiar e sexual, "os seus hábitos de vestir e de falar, os seus gestos, os seus comportamentos na vida pública, as suas formas de ensinar e administrar a escola, os espaços e os tempos escolares e os exemplos que sua figura espelhava". (GONDRA; SCHUELER, 2008, p. 177). Estes aspectos, além de configurarem uma exigência da clientela dos (as) professores (as), também passaram a sê-lo do Estado através de vários dispositivos legais. No caso de Pernambuco, o Regulamento de 12 de maio de 1851 condicionava o exercício da docência à concessão de licenças que, por sua vez, só eram obtidas mediante a apresentação de uma série de documentos, entre os quais figuravam os atestados de boa conduta emitidos pelas autoridades civis e eclesiásticas onde residia o (a) professor (a). Cf. SILVA, 2007; GONÇALVES FILHO, 2010.

${ }^{8}$ Diário de Pernambuco, Recife, 19 jun. 1827.

9 “Dos Deveres dos Mestres e Educadores” In: A Quotidiana Fidedigna, Recife, 02 set. 1834. 
${ }^{10}$ Uma professora do Bairro de $\mathrm{St}^{\circ}$ Antônio, no Recife, dizia, no seu anúncio, ser uma "viúva honesta, bem conhecida nesta Praça”. Diário de Pernambuco, 10 fev. 1831.

${ }^{11}$ Arquivo Público Estadual Jordão Emerenciano (Recife-PE): Petições de Escolas Particulares, 1851, fls. 9.

${ }^{12}$ Diário Novo, Recife, 08 ago. 1842.

${ }^{13}$ O Tesouro de Meninas figurava entre os livros remetidos a Pernambuco no ano de 1799. Contudo, Gilda Verri anota que o nome de Leprince de Beaumont já constava numa listagem de 1795 com o título Le magasin des pauvres, artisans, domestiques, et gens de la campagne. VERRI, 2006, v. 2, p. 64 e 175.

${ }^{14}$ Faremos aqui uso desta edição brasileira reeditada por Ana Maria Machado. Nesta edição, no entanto, foram suprimidos alguns diálogos e as partes do Tesouro referentes às lições de geografia, história sagrada, ciências e história geral. A versão integral pode ser vista no seguinte endereço eletrônico: <http://www.caminhosdoromance.iel.unicamp.br/biblioteca/index.htm>. Acesso em: 20 ago. 2008.

${ }^{15}$ BLANCHARD, 1851. O Tesouro de Meninos consta numa relação de livros enviados a Pernambuco nos idos de 1807. Cf. VERRI, 2006, v. 2, p. 432.

${ }^{16}$ O humanista neerlandês Erasmo de Rotterdam (1466-1536) ficou mais conhecido pelo seu Elogio da Loucura, de 1511. No entanto, o seu Da Civilidade em Crianças, de 1530, alcançou grande sucesso, tendo dezenas de edições. Dirigido às camadas aristocráticas, este manual de etiqueta figurou, para Norbert Elias, como um exemplo da mudança nos padrões de comportamento que visava distanciar a "classe superior" das "outras classes" num momento em que transformações econômicas e políticas punham em evidência novos grupos. Com o tempo, as "lições de boas maneiras" serão apreendidas também pelos outros extratos sociais, de modo que, sendo vulgarizadas e internalizadas, elas constituirão o "homem civilizado". No seu tempo, Erasmo já vê despontar a importância da criança no processo de incorporação dos novos padrões, assim como Blanchard, um de seus prováveis seguidores, no século do iluminismo.

${ }^{17}$ Sobre o papel desempenhado pelo olhar no jogo de sedução e namoro no século XIX ver GONÇALVES FILHO, 2010.

Recebido em: $\quad 02 / 03 / 11$

Aprovado em: $\quad 20 / 04 / 11$ 